\title{
PERBANDINGAN PROBLEM SOLVING DAN PROBLEM POSING DITINJAU DARI KREATIVITAS VERBAL TERHADAP KEMAMPUAN PENYELESAIAN MASALAH IPA
}

\author{
Sulaihah ${ }^{1}$, Mochammad Ahied ${ }^{2}$ dan Irsad Rosidi \\ ${ }^{1}$ Prodi Pendidikan IPA, Fakultas Ilmu Pendidikan, Universitas Trunojoyo Madura, Bangkalan, 69162, \\ Sulaihah26@gmail.com
}

\begin{abstract}
Abstrak
Penelitian ini bertujuan untuk mengetahui pengaruh dan interaksi antara pembelajaran IPA menggunakan model Problem Solving dan Problem Posing dengan kreativitas verbal siswa terhadap kemampuan penyelesaian masalah IPA kelas VIII SMP Negeri 1 Pamekasan tahun ajaran 2017/2018. Penelitian ini merupakan penelitian eksperimen dengan menggunakan desain penelitian Factorial Experimental. Populasi pada penelitian ini adalah seluruh siswa kelas VIII SMP Negeri 1 Pamekasan. Sampel yang digunakan adalah kelas VIII I sebanyak 29 siswa sebagai kelas eksperimen 1 dan kelas VII J sebanyak 30 siswa sebagai kelas eksperimen 2. Teknik analisis data pengujian hipotesis kemampuan penyelesaian masalah IPA siswa menggunakan Uji anava dua jalan dengan desain $2 \times 3$ faktorial dilanjutkan dengan uji lanjut Scheffe dengan program SPSS versi 18.00. Berdasarkan hasil penelitian disimpulkan bahwa: (1) ada perbedaan pengaruh penggunaan model Problem Solving dan Problem Posing terhadap kemampuan penyelesaian masalah IPA siswa; (2) ada perbedaan pengaruh kreativitas verbal terhadap kemampuan penyelesaian masalah IPA siswa; (3) ada interaksi antara pembelajaran IPA menggunakan model Problem Solving dan Problem Posing dengan kreativitas verbal terhadap kemampuan penyelesaian masalah IPA siswa.
\end{abstract}

Kata Kunci : Kreativitas verbal, Problem posing, Problem solving.

\begin{abstract}
The purpose this research of the effect Problem Solving and Problem Posing model, verbal creativity and interaction toward science problem solving skill student's at VIII class Junior High School Negeri 1 Pamekasan study yard 2017/2018. This is research an exsperimental study with use the reseach design Factorial Exsperimental. The population this research is all of the student VIII class I as many 29 student as first exsperimental class and VIII class J as many 30 student as second experimental class. The data analysis technique of hypotesis testing for science problem solving skill student use Anova with 23 factorial design followed by Scheffe method with program SPSS versi 18.00. The result of the research show that: (1) there is an effect using Problem Solving and Problem Posing model to science problem solving skill student's; (2) there is an effect of verbal creativity to science problem solving skill student's; (3) there is interaction between using Problem Solving and Problem Posing model and verbal creativity to science problem solving skill student's.
\end{abstract}

Keywords: problem posing, problem solving, verbal creativity. 


\section{PENDAHULUAN}

IPA merupakan disiplin ilmu yang menekankan pada peristiwaperistiwa yang terjadi dalam kehidupan sehari-hari. Hakikat IPA terdiri atas empat unsur yaitu proses, produk, pengembangan dan aplikasi (Erina dan Kuswanto, 2015). Semua unsur mempunyai nilai tersendiri dan merupakan tolak ukur dalam pembelajaran IPA. Keempat unsur tersebut harus ditekankan, tidak tumpang tindih antara unsur yang satu dengan unsur lainnya dan harus dicapai secara bersama-sama dalam proses pembelajaran. Guru harus merencanakan dan merancang kegiatan pebelajaran agar proses pembelajaran berjalan efektif dan unsur-unsur IPA dapat tercapai secara bersamaan selama proses pembelajaran.

Salah satu upaya untuk merancang dan merencanakan kegiatan pembelajaran, diperlukan pemilihan model pembelajaran yang sesuai dengan materi yang akan diajarkan. Guru harus selektif dalam pemilihan model pembelajaran yang akan diterapkan. Pemilihan model pembelajaran yang tepat merupakan faktor yang dapat mempengaruhi keterampilan berpikir siswa. Model pembelajaran yang tepat dapat menumbuhkan adanya interaksi antara guru dengan siswa. Guru dan siswa aktif selama pembelajaran berlangsung.

Berdasarkan hasil wawancara dengan beberapa siswa SMP Negeri implementasi kurikulum 2013 menyatakan bahwa pembelajaran IPA cenderung membosankan dan sulit dipahami. Guru hanya menggunakan model pembelajaran konvensional dan kurang memperhatikan kondisi siswa. Model pembelajaran konvensional merupakan model pembelajaran yang berpusat pada guru dan tidak melibatkan partisipasi siswa. Guru menjelaskan, siswa mendengarkan, garu aktif dan siswa pasif selama pembelajaran berlangsung.

Berdasarkan data tes hasil belajar siswa pada saat Praktik Pengalaman Lapangan (PPL), sebagian besar rata-rata nilai siswa mata pelajaran IPA tidak tuntas KKM. Siswa yang tuntas KKM hanya sekitar $30 \%$ dari jumlah siswa. Menurut Irawati (2014) menyatakan bahwa rendahnya nilai yang diperoleh siswa disebabkan karena soal-soal yang diberikan kepada siswa cenderung hanya menuntut keterampilan berpikir tingkat rendah. Siswa hanya terlatih dengan soalsoal yang tigkat kesulitannya rendah, sehingga akan merasa kesulitan dalam mengerjakan soal yang tingkat kesulitannya tinggi. Oleh karena itu, siswa harus dilatih dalam mengerjakan soal keterampilan berpikir tingkat tinggi, salah satunya yaitu kemampuan penyelesaian masalah. Kemampuan penyelesaian masalah merupakan upaya mencari solusi dengan proses berpikir tingkat tinggi dalam mencapai tujuan yang memerlukan kesiapan, kreativitas, pengetahuan dan kemampuan serta aplikasinya dalam kehidupan sehari-hari (Hadi dan Radiyatul, 2014).

Model pembelajaran yang efektif untuk melatih kemampuan penyelesaian masalah siswa yaitu model pembelajaran Problem Solving. Model pembelajaran Problem Solving merupakan suatu cara penyajian pembelajaran dengan mendorong siswa untuk mencari dan 
memecahkan suatu pengatahuan atau masalah yang sudah dipelajari (Sugita dkk, 2016). Selain Problem Solving, model pembelajaran yang dapat melatih kemampuan penyelesaian masalah siswa yaitu model pembelajaran Problem Posing. Model pembelajaran Problem Posing merupakan bentuk model pembelajaran yang menekankan pada perumusan masalah atau pengajuan soal oleh siswa beserta jawaban dari masalah atau soal tersebut (Astra dkk, 2012). Kedua model tersebut sama-sama berorientasi terhadap penyelesaian masalah. Sejalan dengan penelitian yang dilakukan oleh Irawati (2014) bahwa model pembelajaran Problem Solving dan Problem Posing dapat meningkatkan hasil belajar siswa, karena model Problem Solving dan Problem Posing bertujuan untuk melatih keterampilan berpikir tingkat tinggi siswa. Menurut Gagne (1985) dalam Sugita dkk (2016) apabila seorang siswa dihadapkan pada suatu masalah, pada akhirnya siswa bukan hanya menyelesaikan masalah melainkan belajar sesuatu yang baru. Siswa akan terbiasa menyelesaikan soal atau masalah dengan tingkat kesulitan berpikir tingkat rendah maupun tingkat tinggi.

Selain model pembelajaran, kreativitas verbal siswa juga dapat mempengaruhi kemampuan penyelesaian masalah IPA. Kreativitas verbal merupakan suatu kemampuan membentuk ide atau gagasan baru, serta menggabungkan ide-ide tersebut ke dalam sesuatu yang baru berdasarkan informasi atau unsur-unsur yang sudah ada, yang mencerminkan kelancaran, kelenturan dan orisinalitas dalam berpikir dalam bentuk verbal (Puspitacandri, 2013). Kreativitas siswa dapat digunakan dalam menyelesaikan masalah yang baru berdasarkan pengetahuan yang sudah dimiliki. Sejalan dengan penelitian yang dilakukan oleh Wahyuddin (2016) membuktikan bahwa semakin baik metakognisi, motivasi belajar, dan kreativitas belajar yang dimiliki siswa, maka kemampuan penyelesaian masalah bagi siswa tersebut semakin tinggi.

Adapun tujuan dalam penelitian ini adalah untuk mengetahui: (1) pengaruh pembelajaran IPA menggunakan model problem solving dan problem posing terhadap kemampuan penyelesaian masalah IPA; (2) pengaruh kreativitas verbal terhadap kemampuan penyelesaian masalah IPA; (3) interaksi pembelajaran IPA menggunakan model problem solving dan problem posing terhadap kemampuan penyelesaian masalah IPA.

\section{METODE}

Penelitian dilaksanakan di SMP Negeri 1 Pamekasan Tahun Ajaran 2017/2018. Adapun waktu pelaksanaan penelitian dimulai bulan April tahun 2018 sampai dengan bulan Mei tahun 2018. Metode penelitian ini adalah metode kuasi eksperimen. Kelompok eksperimen I diberikan perlakuan yaitu pembelajaran IPA menggunakan model problem posing dan kelompok eksperimen II diberi perlakuan pembelajaran IPA menggunakan model problem solving. Teknik pengambilan sampel menggunakan teknik cluster random sampiling. Sampel yang digunakan dalam penelitian ini ada 2 kelas, yaitu kelas VIII I sebagai kelas eksperimen pertama diberi 
perlakuan menggunakan model problem posing dan VIII J sebagai kelas eksperimen kedua diberi perlakuan menggunakan model problem solving.

Desain penelitian yang digunakan yaitu factorial experimental design dengan bentuk $2 \times$ faktorial. Desain penelitian disusun sesuai dengan variabel-variabel yang terlibat. Desain penelitian dapat dilihat pada tabel 1 .

Tabel 1. Desain Penelitian

\begin{tabular}{|c|c|c|c|c|}
\hline & \multicolumn{3}{|c|}{$\begin{array}{l}\text { Kreativitas Verbal Siswa } \\
\text { (B) }\end{array}$} \\
\hline & & $\begin{array}{c}\text { Tinggi } \\
\left(\mathrm{B}_{1}\right)\end{array}$ & $\begin{array}{c}\text { Sedang } \\
\left(\mathrm{B}_{2}\right)\end{array}$ & $\begin{array}{l}\text { Renda } \\
\mathrm{h}\left(\mathrm{B}_{3}\right)\end{array}$ \\
\hline \multirow{2}{*}{$\begin{array}{l}\text { Model } \\
\text { Pembel } \\
\text { ajaran } \\
\text { (A) }\end{array}$} & $\begin{array}{l}\text { Problem } \\
\text { Solving } \\
\left(\mathrm{A}_{1}\right)\end{array}$ & $\mathrm{A}_{1} \mathrm{~B}_{1}$ & $\mathrm{~A}_{1} \mathrm{~B}_{2}$ & $\mathrm{~A}_{1} \mathrm{~B}_{3}$ \\
\hline & $\begin{array}{l}\text { Problem } \\
\text { Posing } \\
\left(\mathrm{A}_{2}\right)\end{array}$ & $\mathrm{A}_{2} \mathrm{~B}_{1}$ & $\mathrm{~A}_{2} \mathrm{~B}_{2}$ & $\mathrm{~A}_{2} \mathrm{~B}_{3}$ \\
\hline
\end{tabular}

Sumber: Modifikasi dari (Setyosari, 2015).

Variabel-variabel yang terlibat dalam penelitian ini merupakan cerminan dari data-data yang akan diperoleh setelah perlakuan terhadap sampel penelitian dilakukan. Variabel terikat dalam penelitian ini adalah kemampuan penyelesaian masalah IPA. Variabel bebasnya adalah model pembelajaran problem solving dan problem posing. Variabel moderatornya adalah kreativitas verbal.

Teknik pengumpulan data dalam penelitian ini menggunakan teknik tes untuk memperoleh data kemampuan penyelesaian masalah IPA siswa dan data kreativitas verbal siswa. Instrumen pelaksanaan pembelajaran dalam penelitian ini berupa silabus, rencana pelaksanaan pembelajaran (RPP), dan lembar kerja siswa (LKS). Instrumen pengambilan data digunakan tes untuk mengetahui kemampuan penyelesaian masalah IPA siswa dan tingkat kreativitas verbal siswa.

Uji normalitas data menggunakan uji Kolmogorov-Smirnov, uji homogenitas menggunakan uji Levene dan uji linieritas menggunakan uji $\mathrm{T}$ sampel bebas. Uji hipotesis menggunakan uji anava tiga jalan melalui program SPSS versi 18. Uji lanjut anava yang digunakan adalah uji Scheffe.

\section{HASIL}

Deskripsi data kemampuan penyelesaian masalah IPA siswa ditinjau dari model pembelajaran untuk kedua kelas eksperimen dapat dilihat pada tabel2.

Tabel 2. Deskripsi Data Kemampuan Penyelesaian Masalah IPA Ditinjau Dari Model Pembelajaran

\begin{tabular}{llccc}
\hline & Kelas & N & Mean & SD \\
\hline KPM & Eksperimen & 29 & 70.76 & 9.504 \\
& 1 & & & \\
& Eksperimen & 30 & 63.40 & 7.959 \\
2 & & & \\
\hline
\end{tabular}

Tabel 2 memperlihatkan bahwa nilai rata-rata kemampuan penyelesaian masalah IPA siswa menggunakan model problem posing lebih tinggi dibandingkan siswa dengan menggunakan model problem solving.

Tabel 3. Deskripsi Data Kemampuan Penyelesaian Masalah IPA Siswa Ditinjau Dari Kreativitas Verbal

\begin{tabular}{ccccc}
\hline & $\begin{array}{c}\text { Kreativitas } \\
\text { Verbal }\end{array}$ & $\mathrm{N}$ & Mean & $\mathrm{SD}$ \\
\hline KPM & Tinggi & 12 & 71.58 & 7.810 \\
& Sedang & 30 & 68.83 & 10.096 \\
& Rendah & 17 & 60.59 & 5.512 \\
\hline
\end{tabular}

Tabel 3 memperlihatkan bahwa nilai rata-rata kemampuan penyelesaian 
masalah siswa dengan kreativitas verbal tinggi lebih baik dibandingkan dengan siswa kreativitas verbal sedang dan rendah. Tabel 4 memperlihatkan bahwa Siswa yang diterapkan model pembelajaran Problem Posing didukung dengan kreativitas yang tinggi mempunyai kemampuan penyelesaian masalah yang lebih baik dibandingkan perlakuan yang lain.

Tabel 4. Deskripsi Data Kemampuan Penyelesaian Masalah IPA Siswa Berdasarkan Interaksi Antara Model Pembelajaran Dan Kreativitas Verbal

\begin{tabular}{lcccc}
\hline \multirow{1}{*}{ Model } & $\begin{array}{c}\text { Kreativitas } \\
\text { Verbal }\end{array}$ & Mean & SD & N \\
\hline Eksperimen & Tinggi & 74,60 & 7,537 & 5 \\
1 & Sedang & 75,13 & 8,374 & 15 \\
& Rendah & 61,33 & 4,472 & 9 \\
Eksperimen & Total & 70,76 & 9,504 & 29 \\
2 & Tinggi & 69,43 & 7,807 & 7 \\
& Sedang & 62,53 & 7,482 & 15 \\
& Rendah & 59,75 & 6,714 & 8 \\
Total & Total & 63,40 & 7,959 & 30 \\
& Tinggi & 71,58 & 7,810 & 12 \\
& Sedang & 68,83 & 10,096 & 30 \\
& Rendah & 60,59 & 5,512 & 17 \\
& Total & 67,02 & 9,437 & 59 \\
\hline
\end{tabular}

Setelah dilakukan uji hipotesis menggunakan anava dua jalan, dapat dirangkum uji hipotesis penelitian pada tabel 5 .

Tabel 5. Hasil Uji Hipotesis Anava Dua Jalan

\begin{tabular}{lrrr}
\hline \multicolumn{1}{c}{ Hipotesis dengan Anava } & $\begin{array}{c}\text { Mean } \\
\text { Square }\end{array}$ & \multicolumn{1}{c}{ F } & Sig. \\
\hline Model & 525,910 & 9,836 &, 003 \\
Kreativitas_Verbal & 550,251 & 10,291 &, 000 \\
Model * Kreativitas_Verbal & 178,180 & 3,332 &, 043 \\
\hline
\end{tabular}

Berdasarkan Tabel 5 diperoleh nilai signifikansi kurang dari 0,05, maka kesimpulan dari pengujian hipotesis dalam penelitian ini adalah sebagai berikut. a. Pengaruh model pembelajaran problem posing dan problem solving terhadap kemampuan penyelesaian masalah IPA

Berdasarkan hasil analisis variansi dua jalan tabel 4 tersebut diperoleh signifikansi 0,003 . Hipotesis nol ditolak karena signifikansi $<0,05$, artinya terdapat perbedaan pengaruh model pembelajaran problem solving dan problem posing terhadap kemampuan penyelesaian masalah siswa. Pembelajaran dengan menggunakan model Problem Solving dan problem posing merupakan model pembelajaran yang berorientasi terhadap penyelesaian masalah melalui kegiatan ilmiah misalnya dalam pembelajaran yaitu diskusi dan eksperimen. Kegiatan diskusi dan eksperimen memicu siswa untuk saling berinteraksi dengan teman lain dalam menyelesaikan masalah. Teori Vygotsky menyatakan bahwa interaksi sosial memegang peranan utama dalam perkembangan kognitif siswa (Jamaris, 2015).

$\begin{array}{ccc}\text { Hasil } & \text { pengujian } & \text { hipotesis } \\ \text { menunjukkan } & \text { adanya } & \text { perbedaan }\end{array}$ pengaruh model problem solving dan problem posing terhadap kemampuan penyelesaian masalah siswa. Program SPSS tidak bisa melakukan uji lanjut karena model pembelajaran hanya terdiri dari 2 kategori yaitu model problem solving dan problem posing. Program SPSS hanya bisa melakukan uji lanjut untuk variabel yang mempunyai lebih dari dua kategori. Model pembelajaran yang lebih baik dalam meningkatkan kemampuan penyelesaian masalah siswa dapat dilihat dari rerata yang dihasilkan.

Kemampuan penyelesaian masalah siswa dengan menggunakan model 
pembelajaran problem posing lebih baik dibandingkan kemampuan penyelesaian masalah siswa menggunakan model pembelajaran problem solving. Siswa dengan penerapan model problem posing diberikan penjelasan materi tiap pertemuan dan perwakilan siswa mengingat kembali informasi yag diperoleh untuk mendapatkan hasil yang optimal sedangkan siswa dengan penerapan model problem solving hanya diberikan permasalahan sesuai dengan materi yang diajarkan. Sejalan dengan penelitian yang dilakukan oleh Irawati (2014) yang menyatakan bahwa model pembelajaran problem posing lebih efektif untuk melatih keterampilan berpikir tingkat tinggi siswa dibandingkan dengan model pembelajaran problem solving.

Penggunaan model pembelajaran problem posing lebih baik dalam meningkatkan kemampuan penyelesaian masalah karena siswa diajak untuk membuat suatu masalah setelah memperoleh informasi selama pembelajaran berlangsung. Membuat masalah beserta penyelesainnya dapat mendorong seluruh siswa lebih aktif selama proses pembelajaran, karena masing-masing siswa dilatih untuk membuat masalah berupa pertanyaan, memahami masalah dan menyelesaikannya serta dapat memberi kesempatan siswa untuk menyelidiki dan membuat jawaban berdasarkan pengetahuan dan informasi yang diperoleh melalui percobaan yang dilakukan tiap pertemuan sesuai lembar kerja siswa yang telah diberikan. Sejalan dengan penelitian yang dilakukan oleh Mulyani dkk (2013) menyatakan bahwa pembelajaran problem posing dapat melatih kemampuan penyelesaian masalah siswa karena siswa menyelidiki dan mencari penyelesaian dari masalah yang diajukan.

Model pembelajaran problem posing merupakan model pembelajaran yang menuntut siswa untuk belajar berulang kali (Koeswardhani dkk, 2015). Pembelajaran dengan model problem posing memberi kesempatan pada siswa untuk belajar melalui sumber belajar yang beragam, penjelasan guru, latihan soal dan pengajuan soal, serta penyelesaiannya sedangkan pembelajaran dengan model problem solving hanya memberi kesempatan pada siswa untuk belajar melalui sumber belajar yang beragam, pemahaman masalah dan penyelesaiannya. Materi yang diperoleh dengan menggunakan model pembelajaran problem solving lebih sedikit dibandingkan dengan problem posing. Siswa kurang terlatih dalam mengerjakan soal berpikir tingkat tinggi sedangkan pada pembelajaran problem posing siswa dilatih melalui soal yang diberikan guru untuk menambah materi selama pembelajaran. Siswa hanya terpacu dari permasalahan yang diberikan guru tanpa memperluas materi yang diajarkan.

b. Pengaruh kreativitas verbal terhadap kemampuan penyelesaian masalah IPA.

Berdasarkan hasil analisis variansi dua jalan tabel 4 diperoleh nilai signifikansi yaitu 0,000 . Hipotesis nol ditolak karena nilai signifikansi $<0,05$, artinya ada perbedaan pengaruh antara kreativitas verbal siswa kategori rendah, 
sedang dan tinggi terhadap kemampuan penyelesaian masalah IPA. Sejalan dengan penelitian yang dilakukan oleh Wahyuddin (2016) yang menyatakan bahwa kreativitas siswa berpengaruh terhadap kemampuan pemecahan masalah siswa. Semakin baik metakognisi, motivasi belajar dan kreativitas belajar yang dimiliki siswa, maka kemampuan pemecahan masalah siswa tersebut semakin tinggi.

Kreativitas verbal berpengaruh terhadap hasil kemampuan penyelesaian masalah siswa karena nilai siswa diambil dari tes kemampuan penyelesaian masalah pada materi getaran, gelombang, bunyi, mekanisme pendengaran pada manusia dan sistem sonar. Soal pada tes kemampuan penyelesaian masalah merupakan soal uraian yang panjang dan ada sebagian menggunakan gambar. Kreativitas verbal yang baik dapat digunakan siswa untuk memahami maksud soal dan cara menyelesaikan soal tersebut secara sistematis sesuai tahaptahap kemampuan peyelesaian masalah meliputi memahami masalah, memahami masalah, merencanakan penyelesaian masalah, melaksanakan penyelesaian masalah dan mengevaluasi hasil penyelesaian masalah.

Hasil uji Scheffe menunjukkan bahwa tidak ada perbedaan pengaruh kreativitas verbal siswa tinggi dan kreativitas verbal siswa sedang terhadap kemampuan penyelesaian masalah IPA siswa yang diperoleh dari nilai signifikansi yaitu $0,549>0,05$. Nilai ratarata kemampuan penyelesaian masalah siswa dengan kreativitas verbal tinggi yaitu 71,58 sedangkan kemampuan penyelesaian masalah siswa dengan kreativitas verbal rendah yaitu 68,83 . Perbedaan nilai rata-rata tidak terlalu signifikan hanya selisih 2,75. Kemampuan penyelesaian masalah siswa dengan kreativitas verbal kategori tinggi dan rendah menunjukkan adanya perbedaan yang diperoleh dari nilai signifikansi yaitu $0,001<0,05$. Nilai ratarata kemampuan penyelesain masalah siswa dengan kreativitas verbal rendah yaitu 60,59. Perbedaan nilai rata-rata cukup signifikan dengan selisih 10,99. Kemampuan penyelesaian masalah siswa dengan kreativitas verbal siswa kategori sedang dan rendah menunjukkan adanya perbedaan yang diperoleh dari nilai signifikansi $0,002<0,05$. Perbedaan nilai rata-rata cukup signifikan dengan selisih 8,24 .

Kemampuan penyelesaian masalah IPA dengan kreativitas verbal tinggi mempunyai nilai rata-rata lebih baik dibandingkan dengan kreativitas verbal rendah dan nilai rata-rata kemampuan penyelesaian masalah IPA dengan kreativitas verbal sedang lebih baik dibandingkan dengan kreativitas verbal rendah. Teori Gestalt menyatakan bahwa proses pemecahan masalah merupakan proses belajar yang berlangsung dalam serangkaian proses mengandung tujuan, penjelasan, imajinasi dan kreativitas (Jamaris, 2015).

Kemampuan penyelesaian masalah IPA dengan kreativitas verbal tinggi dan kreativitas verbal sedang menunjukkan tidak ada perbedaan pengaruh 16 sedangkan kreativitas verbal siswa berpengaruh terhadap kemampuan penyelesaian masalah IPA. Sejalan dengan penelitian yang dilakukan oleh Rosyada (2018) yang menyatakan bahwa 
siswa dengan kreativitas belajar tinggi mempunyai prestasi belajar yang sama baiknya dengan siswa kreativitas belajar sedang. Seharusnya siswa dengan kreativitas verbal yang tinggi mempunya kemampuan penyelesaian masalah IPA yang lebih baik dibandingkan dengan siswa dengan kreativitas verbal sedang. nilai rata-rata kemampuan penyelesaian masalah dengan kreativitas verbal sedang lebih tinggi dibandingkan dengan kreativitas verbal tinggi dengan selisih yang tidak terlalu signifikan. Hal ini disebabkan karena frekuensi siswa yang mempunyai kreativitas verbal tinggi lebih sedikit yaitu 12 dibandingkan dengan frekuensi siswa yang mempunyai kreativitas verbal sedang yaitu 30. Oleh karena itu, sampel penelitian diperlukan peningkatan tingkat kreativitas agar frekuensi masing-masing kategori kreativitas verbal tidak terlalu berbeda. Munandar dalam Puspitacandri (2013) mengungkapkan bahwa lingkungan merupakan faktor yang utama terjadinya proses perkembangan intelegensi dan merupakan dasar untuk pertumbuhan kreativitas verbal.

c. Interaksi model pembelajaran problem solving dan problem posing dengan kreativitas verbal terhadap kemampuan penyelesaian masalah IPA

Berdasarkan hasil analisis variansi dua jalan tabel 4.15 diperoleh nilai signifikansi yaitu 0,043 . Hipotesis nol ditolak karena nilai signifikansi $<0,05$, artinya Ada interaksi antara penggunaan model pembelajaran problem solving dan problem posing dengan kreativitas verbal siswa terhadap kemampuan penyelesaian masalah IPA. Sejalan dengan penelitian yang dilakukan oleh Sugihardjo dkk (2014) yang menyatakan bahwa terdapat interaksi antara model pembelajaran problem solving dan problem posing dengan kreativitas siswa terhadap prestasi belajar.

Grafik interaksi penggunaan model pembelajaran dengan kreativitas verbal tidak berpotongan, sehingga termasuk pola interaksi ordinal. Interaksi ordinal terjadi ketika rata-rata kelompok pada satu kategori selalu lebih tinggi atau rendah dari pada kategori yang lain pada perlakuan yang sama walaupun dengan perlakuan yang lain (Harjono, 2012). Ada tidaknya interaksi yang signifikan dilihat dari nilai signifikansi hasil dari pengujian hipotesis uji Anava dua jalan (Budiyono, 2016). Berdasarkan nilai rata-rata dari tabel 4.7, grafik interaksi penggunaan model pembelajaran dengan kreativitas verbal dapat dilihat pada gambar 1 .

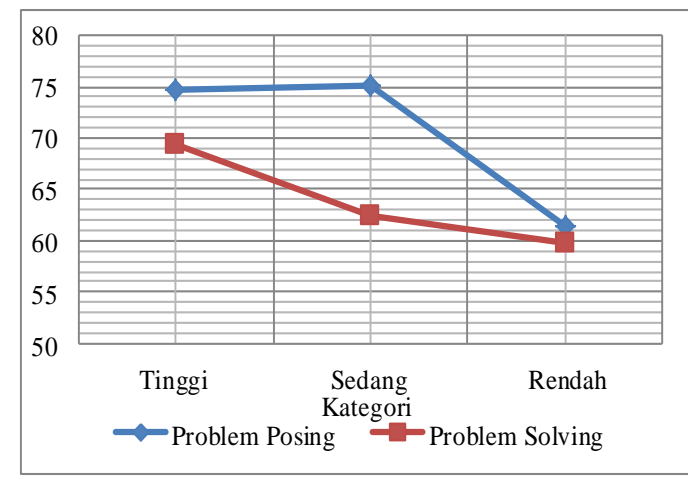

Gambar 1. Grafik Interaksi Model Pembelajaran dan Kreativitas Verbal

Pengujian hipotesis menunjukkan bahwa ada interaksi penggunaan model pembelajaran Problem Posing dan Problem Solving dengan kreativitas verbal terhadap kemampuan penyelesaian masalah IPA. Uji lanjut 
Anava dilakukan uji lanjut Scheffe.Uji Scheffe menunjukkan bahwa ada perbedaan kemampuan penyelesaian masalah siswa antara siswa yang menggunakan model pembelajaran Problem Posing dengan kreativitas tinggi dan model pembelajaran Problem Solving dengan kreativitas rendah, siswa menggunakan model pembelajaran problem posing dengan kreativitas sedang dan model pembelajaran problem posing dengan kreativitas rendah, siswa menggunakan model pembelajaran problem posing dengan kreativitas sedang dan model pembelajaran problem solving dengan kreativitas rendah.

Kemampuan penyelesaian masalah siswa menggunakan model pembelajaran problem posing dengan kreativitas tinggi lebih baik dibandingkan dengan menggunakan model pembelajaran problem soving pada setiap kategori kreativitas verbal siswa. Kemampuan penyelesaian masalah siswa dengan kreativitas verbal tinggi lebih baik dibandingkan dengan model kreativitas verbal rendah dan sedang pada model pembelajaran problem posing dan problem solving, kecuali antara kreativitas verbal siswa kategori tinggi dan sedang menggunakan model pembelajaran problem posing karena tidak terdapat perbedaan pengaruh kreativitas verbal kategori sedang dan rendah terhadap kemampuan penyelesaian masalah siswa dengan perbedaan nilai rata-rata yang tidak terlalu signifikan dengan selisih 0,53. Berdasarkan uraian di atas dapat disimpulkan bahwa ada interaksi antara penggunaan model pembelajaran problem solving dan problem posing dengan kreativitas verbal siswa terhadap kemampuan penyelesaian masalah IPA.

\section{SIMPULAN DAN SARAN}

Hasil dari penelitian ini dapat disimpulkan sebagai berikut : yang pertama yakni ada perbedaan pengaruh model problem solving dan problem posing terhadap kemampuan penyelesan masalah IPA siswa. Yang kedua ada perbedaan pengaruh kreativitas verbal siswa terhadap kemampuan penyelesaian masalah IPA siswa. Selanjutnya ada interaksi antara pengaruh penggunaan model pembelajaran problem solving dan problem posing dengan kreaivitas verbal siswa terhadap kemampuan penyelesaian masalah IPA.

Saran untuk penelitian ini yang pertama yakni guru harus mampu memperhatikan kreativitas verbal siswa selama pembelajaran dan diperlukan peningkatan kreativitas siswa untuk memperoleh hasil yang lebih optimal. Untuk selanjutnya akan dilakukan penelitian lebih lanjut yaitu perbandingan model Problem Solving dan Problem Posing dengan menambahkan variabel moderator yang lain seperti sikap ilmiah, motivasi, gaya belajar dan minat belajar siswa pada mata pelajaran lain dan jenjang pendidikan yang berbeda untuk meningkatkan kualitas pendidikan.

\section{DAFTAR PUSTAKA}

Astra, I.M., Umiatin, dan Jannah, M. 2012. "Pengaruh Model Pembelajaran Problem Posing Tipe Pre-solution Posing terhadap Hasil Belajar Fisika dan Karakter Siswa SMA". Jurnal Pendidikan Fisika Indonesia. Volume. 8, No. 02.

Budiyono, 2016. Statistika untuk Penelitian. Surakarta: UNS Press.

Erina, R dan Kuswanto, H. 2015. "Pengaruh Model Pembelajaran InSTAD terhadap Keterampilan Proses Sains dan Hasil Belajar Kognitif Fisika di SMA". Jurnal Inovasi Pendidikan IPA. Volume. 1, No. 2. 
Hadi, S dan Radiyatul. 2014. "Metode Pemecahan Masalah menurut Polya untuk Mengembangkan Kemampuan Siswa dalam Pemecahan Masalah Matematis di Sekolah Menengah Pertama". Jurnal Pendidikan Matematika. Volume. 2, No. 1.

Harjono, Ahmad. 2012. "Perbedaan Starategi Pembelajaran dan Pemberian Advance Organizer Pengaruhnya terhadap Hasil Belajar Fisika SIswa Kelas X. Jurnal Pijar Mipa. Volume. 8, No. 1.

Irawati, R.K. 2014. "Pengaruh Model Problem Solving dan Problem Posing serta Kemampuan Awal terhadap Hasil Belajar Siswa'. Jurnal Pendidikan Sains. Volume. 2, No. 4.

Jamaris, M. 2015. Orientasi Baru dalam Psikologi Pendidikan. Bogor: PT Ghalia Persada.

Koeswardhani, Y., Mulyani, B., dan Masykuri. M. 2015. "Pengaruh Model Pembelajaran Problem Solving dan Problem Posing pada Pokok Bahasan Konsep Mol terhadap Prestasi Belajar Siswa Kelas X Semester Genap SMA Negeri 6 Surakarta Tahun Pelajaran 2013?2014. Jurnal Pendidikan Kimia. Volume. 4, No. 1.

Mulyani, B., Sriwenda, A., dan Yamtinah, S. 2013. "Penerapan Pembelajaran Model Problem Posing untuk Meningkatkan Kreativitas dan Prestasi Belajar Siswa pada Materi Laju Reaksi Kelas XI IPA 5 SMA Negeri 1 Boyolali Tahun Pelajaran 2012/2013". Jurnal Pendidikan Kimia. Volume. 2, No. 2.

Puspitacandri, A. 2013. "Pengaruh Kreativitas Verbal terhadap Sense of
Humor Siswa Akselerasi”. Jurnal Psikologi Tabularasa. Volume. 8, No. 2.

Rosyada, A., Budiyono, dan Setiawan, R. 2018. "Eksperimentasi Pembelajaran Matematika dengan Model Kooperatif Tipe STAD (Students Teams Achievement Divisions). Jurnal Pendidikan Matematika dan Matematika. Volume. 11, No. 1.

Setyosari, P. 2015. Metode Penelitian Pendidikan dan Pengembangan. Jakarta: Prenadamedia Group.

Sugihardjo, Mardiyana, dan Riyadi. 2014. "Eksperimentasi Model Pembelajaran Problem Posing dan Problem Solving pada Materi Trigonometri ditinjau dari Kreativitas Peserta Didik Kelas XI IPA SMA Se-kabupaten Kudus Tahun Ajaran 2013/2014. Jurnal Elektronik Pembelajaran Matematika. Volume. 2, No. 5.

Sugita, N.T.H., Ashadi, dan Masykuri, M. 2016. "Pengaruh Model Pembelajaran Problem Solving dan Problem Posing terhadap Hasil Belajar Ditinjau dari Kreativitas Siswa pada Materi Termokimia Kelas XI SMA Negeri 1Karanganyar Tahun Pelajaran 2015/2016". Jurnal Pendidikan Kimia. Volume. 5, No. 2.

Wahyuddin, 2016. "Pengaruh Metakognisi, Motivasi Belajar, dan Kreativitas Belajar terhadap Kemampuan Pemecahan Masalah Siswa Kelas VIII SMP Negeri 2 Sabbangparu Kabupaten Wajo". Jurnal Daya Matematis. Volume. 4, No. 1. 